\title{
An arbor of one's own? Aemilia Lanyer and the early modern garden
}

\section{CHRISTINE COCH}

Le jardin d'agrément de la Renaissance offrait aux femmes un accès inaccoutumé à un espace produit de l'art et où elles pouvaient exercer une puissance créatrice. Le statut ambigu du jardin, à la fois comme extension de l'espace public de la résidence et comme lieu retiré et plus intime, procure un site tout à fait adapté à l'expression dramatique des difficultés de la femme écrivain, déchirée entre les contraintes sociales et la volonté d'expression personnelle artistique. Pour Aemilia Lanyer, le jardin joue ces deux rôles. En tant que sanctuaire pour elle et son mécène, le jardin de Cookham inspire la vision utopique d'un monde acceptant son travail en tant que poète. Or, ce même jardin, par sa perméabilité à l'ordre social extérieur, laisse apercevoir également les limites du jardin comme vision utopique. Ultimement, Lanyer réfute au jardin sa capacité de servir d'analogie à son art comme refus de soumission aux iniquités de l'ordre.

$\mathrm{O}$

ut of the handful of English women poets who published original work in the sixteenth and early seventeenth centuries, four authorized their writing - in disparate ways, and with varied degrees of success-by reference to a garden. Consider Isabella Whitney, who opens A Sweet Nosgay, or Pleasant Posy (1573) with the admission that she "did step into an others garden for these Flowers... of an others growing, yet... of my owne gathering and makeing up."1 Even as she safeguards her work by associating it with the suitably feminine activities of picking flowers and translating male authors' texts, she looks forward to a moment when she can propose a more satisfactory metaphor for her art, which in fact includes a good deal of original verse. "Yf you take pleasure in [these SLIPS]," she promises her patron, "I shal... be occasioned to endevour my selfe to make a further viage for a more dayntier thing (then Flowers are) to present you withall" (A5r). By the early 1620s, Rachel Speght and Mary Wroth are able to reimagine the garden as a site where a female poet can work toward reconciling her art with social 
expectations. In the dream vision Mortalities Memorandum (1621), Speght as dreamer longs to enter "Eruditions garden." But first she must face down Disswasion's protests, "As dulnesse, and my memories defect; / The difficultie of attaining lore, / My time, and sex, with many others more" (106-8). The dreamer's first-person phrasing shows she has already internalized the ideological norms Disswasion voices. The garden is the dreamer's reward for grappling with the culture's biases, a temporary retreat from patriarchal pressures that readies her for engaging her worldly antagonists in her writing. In Mary Wroth's The Countess of Montgomery's Urania (1621), the poet Pamphilia likewise struggles to assimilate gendered codes of behavior with rival desires. Like Speght's dreamer, again and again she grapples with doubts, pursues enlightenment, and writes verse - all within the protective walls of a garden "sett and ordered by her hand."

Gardens, women, and poetry had long been associated in sixteenth-century verse written by men, typically as sources of analogous pleasures. Numerous lyric mistresses walk or sit among cultured flowers that mirror their charms, enticing viewers' senses to more or less unsettling effect. Embowered temptresses like Chapman's Corinna and Spenser's Acrasia press the seduction further, embodying the period's moral ambivalence toward sensual pleasure, and, by extension, this aspect of art and poetry. This paper examines the earliest female poet to reclaim the figure of the woman in the garden in order to address at length her own vexed relationships to aesthetic pleasure and art, Aemilia Lanyer. Like Whitney, Speght, and Wroth, as a woman Lanyer was at least as concerned about the social conditions of public authorship as she was about the moral implications of poetry as an art, and the garden she recreates in "The Description of Cooke-ham" (1611) manifests this double burden.

To account for why so many of the age's female poets adapted this problematic image, laying claim to the garden as a site for women's writing, I begin by tracing how gardens figured materially and ideologically in their lives as female members of early modern households. Diaries, letters, and household manuals suggest that the contemporary pleasure garden offered women unusual access to a space of creative artifice. Moreover, the art of gardening was often likened to poesy, a link that strengthened as gardening gained status as a liberal art in the seventeenth century. A pleasure garden's ambiguous status as an extension of the public dimensions of the household as well as a more intimate sphere apart provided a site uniquely suited to dramatize the predicament of the female writer, caught between social constraints and a will to artful self-expression. The garden at Cookham plays both roles for Aemilia Lanyer. As a sanctuary for her and her patron, it in- 
spires a utopian vision of a world that supports her work as a poet. Yet in its permeability to the social order beyond, it also registers this vision's limits. Ultimately Lanyer rejects the garden as an analogue of her art to protest her subjection to that order's inequities.

The early modern English garden was a contested space from the perspective of gender. On one hand, Western European culture had commonly assigned the garden to the housewife's domain. Thomas Tusser took this division of labour for granted in the sixteenth century, advising readers of his popular handbook on husbandry and household management that

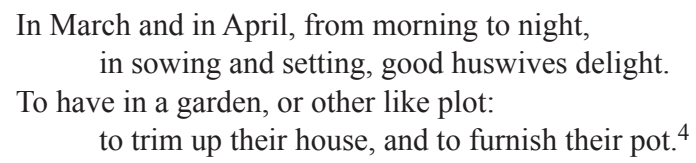

His contemporary Barnabe Googe, translating German writer Conrad Heresbach, affirms that a garden's condition reflected a housewife's skill. "Herein were the olde husbandes very careful, and used alwayes to judge, that where they founde the Garden out of order, the wyfe of the house (for unto her belonged the charge thereof) was no good huswyfe." 5 Such beliefs were rooted in "ancient Roman law," which "acknowledged the relationship" between the "vernacular or working garden" and the "woman of the house" who tended it, controlling "the planting and cultivation, and the eventual distribution of the produce." 6 Thomas Hill tracks this legacy in The Gardener's Labyrinth, a handbook he originally published in 1577 , writing under the pseudonym Didymous Mountaine. In Rome, Hill says, male gardeners' success

\begin{abstract}
allured them... to place and frame Gardens, as well within Cities and Towns as fast by, that a cost bestowed, might after possesse the procreation and delight of minds, besides the proper gaine made by the fruits, flowers, and herbs, gathered in them. The Garden plots at length grew so common among the meaner sort, that the charge and the chiefest care of the same, was committed unto the wife, insomuch that these accounted not the wife of the house to be a huswife indeed, if she bestowed not paines and deligence, as Cato reporteth, in the weeding, trimming, and dressing of the Garden. ${ }^{7}$
\end{abstract}

Yet Hill's text only indirectly bears witness to a reversal of this transfer of gender roles in early modern English culture. Women had never fully displaced men in the garden, ${ }^{8}$ and as gardens gained size and importance as registers of a family's status, pleasurable retreats, and emblems of art's capacity to master the natural order, men moved to reclaim them, supported by a proliferation of handbooks like Hill's. ${ }^{9}$ Gardens had never fit comfortably into what Susan Dwyer Amussen calls the "schematic terms" by which 
"household manuals described the family economy and sexual division of labor." Amussen notes that "some authors divided the roles of husbands and wives into getting and spending (clearly a more urban conception), but others saw the division as a spatial one of outside (men) and inside (women)." ${ }^{10}$ As a source of products a household would consume, the garden belonged in the husband's domain under the getting/spending dichotomy. But its practical proximity to the wife's tasks of cooking, preparing medicinal simples, and ornamenting the house aligned it with her work. Nor was the garden easily subsumed under the categories "inside" and "outside." Although obviously out of doors, it was also always protected by an enclosure, ${ }^{11}$ much like "the house, the dairy, the brewhouse, [and the] poultry" that country wives traditionally tended. ${ }^{12}$ Together, these circumstances problematized the garden's status as what Laurie Shannon has termed part of "the 'proper' zone of female persons accorded by the conduct books and gender ideology of the period" that could ultimately "take on a "proprietary' sense, affectively and erotically." 13 If a woman claimed the garden as her own, she did so in defiance of competing male claims.

When she succeeded, the rewards surpassed those attached to the more straightforwardly feminine areas of the household, where she performed or oversaw largely utilitarian labour. Unlike the dairy, brewhouse, or poultry, even the most practical gardening had an aesthetic dimension. This is particularly emphasized in the first printed English gardening handbook addressed specifically to women, The Countrie Housewifes Garden (1617). In it William Lawson advises his female reader to set a plot of "flowres" apart from her functional "kitchin Garden." But even so, he urges,

[t]hough your Garden for flowers doth in a sort peculiarly challenge to it selfe a profite, and exquisite forme to the eyes, yet you may not altogether neglect this, where your hearbes for the pot doe grow. And therefore, some here make comely borders with the Hearbes aforesaid. The rather because aboundance of Roses and Lavander yeeld much profite, and comfort to the sences. ${ }^{14}$

Even the language of pleasure and utility merge as Lawson insists that a garden's "profite" always extends to aesthetic delight. Beyond ornamental borders, Googe describes rosemary topiary "sette by women for their pleasure to growe in sundry proportions, as in the fashion of a Cart, a Pecock, or such like thing as they fancie." 15 Lawson goes on to provide patterns for knots, although only a "few, choyce new formes," since "the number of formes, mazes and knots is so great, and men are so diversly delighted" that he finally leaves "everie Housewife to her selfe" in designing her beds. ${ }^{16}$ Because Lawson addresses a "countrie housewife" with limited means, he does not dis- 
cuss the type of larger-scale estate garden Aemilia Lanyer is concerned with at Cookham, yet there too the same aesthetic imperatives applied. Beyond kitchen gardens and knot or parterre gardens near the house, estate gardens commonly included orchards and a "wilderness" or "wood." Trees in both orchard and wilderness often were planted in geometrical patterns, leaving space for straight or winding shaded walks. Orchards might also be planted with flowers and beautified with mounts, sundials, statues, and topiary. Many wildernesses sheltered banqueting houses, arbours, and fountains amid their densely set trees. ${ }^{17}$ Although Lanyer records no such overtly artificial features at Cookham, the naturalistic landscape she describes would have been planned by gardeners to achieve specific aesthetic effects.

Other household tasks besides gardening afforded women opportunities to exercise aesthetic sensibility, as in preparing the often elaborately ornamented dishes in the period's cookbooks, or designing embroidery patterns. But such activities were understood as skilled yet essentially manual crafts. By contrast, gardening was gaining respectability as a liberal art in the late sixteenth and early seventeenth centuries. Botany flourished, and engineers contributed ever more elaborate waterworks to the great estates, redefining the garden as a site revealing the inner workings of nature. Scientific attention was bolstered by unprecedented royal and gentle interest under the Stuarts, elevating gardening to a pursuit that could be subjected to systematic intellectual analysis by writers like Francis Bacon. Thanks to their long experience in gardening, and assisted by the new handbooks, women of the period began to access the conventionally masculine realm of art. As Rebecca Bushnell remarks, manuals increasingly geared to "less privileged gardeners" emphasized experience over classical texts as the basis of expertise, ${ }^{18}$ a shift away from formal learning that further helped to make horticultural authority available to women. In Hugh Platt's Floraes Paradise, a "volume of experimentall observations," for instance, we find recorded alongside the work of "diverse gentlemen of good skill and practice" achievements of female gardeners like "Mistresse Hill," who offers a new way of cultivating "carnations, wallflowers, \& stock-gilliflowers."19 Lady Margaret Hoby extended her understanding of plants' natural properties into medicine, studying herbals and treating patients when she was not "busie in [her] garden." In 1603 she reports, "we had in our Gardens a second sommer, for Hartechokes bare twisse, whitt Rosses, Read Rosses: and we, havinge sett a musk Rose the winter before, it bare flowers now. I think the Like hath seldom binnseene: it is a great frute yeare all over." ${ }^{20}$ Her obvious delight in the unexpected returns of an Indian summer evinces an easy expertise in the garden, harmon- 
izing nature with art in what Bacon would later label "the purest of human pleasures." 21

Bushnell perceptively compares gardening manuals' redefinition of authority as experience to a parallel shift in contemporary poetics. ${ }^{22}$ Much as a privileging of hands-on experience profited female gardeners, a new emphasis on the nuances of English vernacular over Latin models may have empowered female poets like Aemilia Lanyer to position themselves relative to an art dominated by men. Furthermore, women's success as gardeners may have encouraged female poets more directly via the parallels commonly drawn between the two arts by contemporary theorists. The classical image of the Muses' garden, or “Apollo's garden" in Philip Sidney's version of the trope, fuses the arts in countless period texts. ${ }^{23}$ George Puttenham likens poesy to gardening in lauding the poet's power over nature: "in that [the poet] speaks figuratively, or argues subtillie, or perswades copiously and vehemently, he doth as the cunning gardiner that using nature as a coadjutor, furders her conclusions \& many times makes her effectes more absolute and straunge." 24 Sidney likewise describes the "golden" world that poesy creates as a ravishing artificial landscape. "Nature never set forth the earth in so rich a tapestry as divers poets have done; neither with so many pleasant rivers, fruitful trees, sweet-smelling flowers, nor whatsoever else may make the too much loved earth more lovely." 25

Like Sidney and Puttenham's poesy, gardening enabled women to create "miniature worlds" manifesting their thoughts and desires more completely than the "real" world ever would. ${ }^{26}$ Handbook writer Gervase Markham extols this aspect of the art, at least for men.

The adornation and beautifying of gardens is not onely divers but almost infinite, the industry of mens braines hourely begetting and bringing forth such new garments and imbroadery for the earth, that it is impossible to say this shall be singular, neither can any man say that this or that is the best, sith as mens tastes so their fancies are carried away with the varietie of their affections. ${ }^{27}$

For women, as we have seen, Lawson's counsel is more guarded, with only a glancing reference to paradoxically masculine "delight" ("men are so diversly delighted"). Yet even if Lawson resists acknowledging feminine desire, handbooks like his catered to it in practice, supporting the pursuits of women like Lucy, Countess of Bedford, who developed her "love of horticulture" after she retired from court. ${ }^{28}$ Her appetite for collecting beautiful specimens for her gardens at Moor Park animates a 1618 letter to Lady Cornwallis: 
This monthe putts me in minde to intreate the performance of your promisse for som of the little white single rose rootes I saw att Brome, \& to chalenge Mr Bacon's promis for sum flowers, if about you ther be any extraordinary ones; for I am now very busy furnishing my gardens.

Earlier she frames her enthusiasm for all her renovations at the estate as erotic infatuation. Again she writes of her "workes att the More, whear I have binne a patcher this sommer, and I am still adding som trifles of pleasure to that place I am so much in love with, as, if I wear so fond of any man, I wear in hard case." ${ }^{29}$ Her intense feelings for the estate clearly correlate with her capacity to reshape it at her pleasure - here, signally, in the absence of a dominant male. Even for women less well-to-do than Lucy, like the country housewives Lawson proposes knots for, more modest gardens could offer cherished opportunities for creative self-expression.

One reason gardens afforded this freedom, particularly on sizeable estates, was their position on the edge of the dominant social order. While a household's gardens were often thoroughly integrated into the everyday patterns of labour and social obligation, at other moments they afforded the privacy women needed to imagine alternative ways of living. ${ }^{30}$ Comparable privacy was hard to come by within the household proper. Although architectural innovations in aristocratic homes increasingly provided retreats for solitude and intimacy, ${ }^{31}$ their use was controlled within the domestic framework, which mirrored the larger social structure. ${ }^{32}$ Pleasure gardens offered a less restrictive option. Still protected by enclosing walls, new-style gardens tended not to be fully visible from the house as the old-style knot gardens had been, often extending down terraced hillsides and incorporating covered grottoes, dense groves, orchards, and ornamental parks. Unlike a closet, whose constricted space obliged the solitary woman to withdraw into her thoughts, a garden invited her to look inward and outward at once, contemplating her relation to her surroundings. A diary entry captures one Anne Slingsby drawing the distinction in 1617. Protesting charges of melancholy, she insists, "the moste of my time I spend ether in my closet reading, or in the garden walkeing and meditateing what I have read." 33 The formidable Anne Clifford also records using her garden for private devotions, as well as for reflecting on worldly affairs. In May of 1616 she recalls that "about this time" at Knole "I used to rise early in the Morning \& go to the Standing in the garden, $\&$ taking my Prayer Book with me beseech God to be merciful to me in this \& to help me as He always hath done." The following March she describes a day she "spent walking in the Park with Judith, carrying my Bible with me, thinking on my present Fortunes \& what troubles I have passed through." On occasions like these the garden provided a refuge from the legal 
and domestic wrangling Anne contended with in the patriarchal sphere. Yet at other times it merged with this sphere, as later in the same month when she "walked abroad with my Lord in the Park and the garden, where he spake to me much of this Business with my Uncle." Or in June, when one day "after supper" she "walked in the garden and gathered Cherries and talked with Josiah who told me he thought all men in the House loved me exceedingly, except Matthew and 2 or 3 of his Consorts." 34

Although she does not describe the experience in her diaries, before her first marriage Anne spent time with her mother, Margaret, Countess of Cumberland, in the gardens at an estate near Cookham in Berkshire. They were accompanied by Aemilia Lanyer, who used the garden's shifting status as retreat and social space to write the "The Description of Cooke-ham," England's first vernacular estate poem and a meditation on what it meant to be a woman poet of modest means in the service of an aristocratic patroness. To portray this relationship in its ideal state, Lanyer capitalizes on the garden's cultural availability as a space of female art and an analogue of poetry to imagine an all-female poetic paradise provisionally set apart from the competing needs of male-dominated society. In so doing, she refashions the sixteenth-century literary trope of the woman in the garden to represent the symbiotic relationship of female writer and female reader, using the garden to render the virtuous pleasures of a female poet's voice as palpable natural objects offering themselves to Margaret, their grateful patroness.

In aligning garden, woman, and poetry, Lanyer follows Spenser, Chapman, and other sixteenth-century poets, but she prefigures later writers like Andrew Marvell by claiming morally flawless pleasures for the complex, here grounded in Protestant piety. ${ }^{35}$ A garden's privacy offered women a physical place for the spiritual space allowed them in Protestant traditions. Like Anne Clifford carrying her prayer book into the park at Knole, in a garden's shaded quiet women could approach their God without mediation, confident their souls were equal to all others in his sight. Lady Hoby often retreated to a garden by herself or with her chaplain to make her devotions, as at Linton on August 23,1599, where she "cam in and walked in the garden, medetatinge of the pointes of the sarmon and prainge tell hard before I went to supper." At Callowdon House in Warwickshire, the late sixteenth-century garden's banqueting house was "the polite work of the Lady Elizabeth, wife of Sir Thomas Berkeley... and the retired cell of her soul's soliloquies to God her creator." 36 A mid seventeenth-century garden in Hackney provided a similar refuge to young Susanna Perwich: 


\begin{abstract}
Indeed that was one of the matters of her complaint, that she wanted conveniency for retirement, where she might fully vent her Soul to God, without disturbance or observation; and therefore because the house was alwayes full of company... so that she could get no place of privacy; her manner was in the daytime to get into the Garden, at such hours when others might not so freely come in to it, and there with her Bible, or some other choice Book, spent an hour or more in Reading, Meditation, and such ejaculations as she could send up to Heaven in walking at which seasons, she hath sometimes said to such as she was wont to tell her mind to, her heart hath been as much warmed and refreshed in converse with God, as when she hath been most affected upon her knees elsewhere. ${ }^{37}$
\end{abstract}

In Lanyer's volume of poetry, the garden's devotional role informs the dedication to Lucy, Countess of Bedford, whose heart is figured as a "blessed bowre," a "bed of rest" Christ fills with "Flowres of fresh comforts" and "such rich beauties as may make it blest." 38 The imagery resonates with the Canticles, fusing physical and spiritual delight.

The same fusion distinguishes the garden at Cookham, where Lanyer portrays a trio of women enjoying the complementary pleasures of a beautiful setting and the loving companionship of pious souls. Never does she allow the garden's sensuous charms to distract from its spiritual significance. Whereas descriptions of the locus amoenus traditionally catalogue appeals to all the senses, only a few senses are featured by Lanyer, primarily sight and hearing, the highest of the five. ${ }^{39}$ And she makes no effort to evoke their satisfactions so that the reader can experience them firsthand. Instead, the pleasures appear as signifiers with higher meaning, always and immediately available. In all the garden's "beauties" Lanyer's Countess perceives God's "beauty, wisdome, grace, love, majestie" (11. 79, 80). She conflates the book of nature with the book of scripture by placing "his holy Writ in some faire tree, / To meditate what [she] therein did see," and moves through the garden's landscape in discourse with "Christ and his Apostles," or in the company of "Moyses" ascending "his holy Hill" (11. 83-4, 82, 85). For herself, Lanyer lauds Cookham as the place she "first obtain'd / Grace from that Grace where perfit Grace remain'd," where multiple levels of apprehension, mundane to mystical, merge in a unified whole (11. 1-2).

It is also "where the Muses gave their full consent, / I should have powre the virtuous to content," Lanyer continues, linking Cookham's multi-leveled pleasures with her art (11. 3-4). She consistently celebrates poetry-and specifically women's poetry-for its integration of sensuous delight and higher meaning. Other sources of beauty are problematic, such as a woman's "outward Beautie," which draws "dangers and disgrace" by attracting men's lustful advances or corrupting the woman herself. 40 But the Muses' "godly labours doe avoyd the baite / Of worldly pleasures." ${ }^{41}$ Mary Sidney's verse 
epitomizes the blend of sense and virtue: "With contemplation of Gods powrefull might, / Shee fils the eies, the hearts, the tongues, the eares / Of after-comming ages." Though Art and Nature combine to ravish her readers' senses, they do so in service of "Her love, her zeale, her faith and pietie." 42 At Cookham, the garden doubles poet and poem in paying tribute to Margaret's "grace." 43 Poem and estate both "frame" "new delight[s]" in honour of her visit $(11.18,17)$, while the garden's songbirds echo Lanyer's verse:

The little Birds in chirping notes did sing, To entertaine both You and that sweet Spring. And Philomela with her sundry leyes,

Both You and that delightfull Place did praise. (11. 29-32)

Lanyer raises the question of how the pleasures of poet, poem, and garden should be valued by the Countess in her opening address, advancing a range of options. She first suggests that Cookham's "pleasures past," as preserved in the poem, be viewed as "fleeting worldly Joyes that could not last" (11. 12-4). Perhaps these transient joys should give way to higher priorities, like the "worldly pleasures" virtuous women shun in other parts of the volume. ${ }^{44}$ Or perhaps despite their fragility and imperfection they deserve to be cherished. Or possibly, she then proposes, they ought to be prized as something more profoundly sustaining, "dimme shadowes of celestiall pleasures / Which are desir'd above all earthly treasures" (11. 15-6).

She underscores her role in creating their value, wherever it falls on the scale, by figuring poesy as service. Like the garden walks that don 'Liveries,' or the birds that 'entertaine' Margaret at Cookham, she writes as a devoted servant fulfilling the Countess' "noble hest" (11. 207). What we know of her life suggests that she may already have been in the Cliffords' service as a professional musician and possibly Anne's music teacher, positions that would have accustomed her to the idea of producing public art for a patron/ employer. ${ }^{45}$ She foregrounds her poetic labour with first-person tags that prevent garden and poet from merging entirely and allowing art to obscure the artist. In lines like "Oh how (me thought) against you thither came, / Each part did seeme some new delight to frame!" (11. 17-8) she draws attention to the interpretive work that transforms the estate from a mundane borrowed property into a magically responsive haven. Her "language of acknowledged simile and poet's surmise" 46 constantly reminds the reader that her fancy makes the garden meaningful, as in the case of the oak "seeming joyfull in receiving" Margaret into its branches, or the "Hills, vales, and woods" that appear before her "as if on bended knee" (11. 60, 68, emphasis mine). Lanyer breathes life into Cookham as overtly as it inspires her poem, a dynamic nice- 
ly captured by the agent ambiguity in "Those pleasures which my thoughts did then unfold" (1. 10).

In refiguring the landscape to convey meaning, she acts as Puttenham's poet/gardener, who "using nature as a coadjutor, furders her conclusions \&... makes her effectes more absolute and straunge." The analogy between garden and poem helps to naturalize the poetic authority she lays claim to by relating it to an art more conventionally open to women and increasingly associated with liberal learning. In a poem intent on displaying the poet's shaping powers, her choice of a comparatively unstructured pleasure park in lieu of a more formal knot or parterre garden may seem curious. Yet Lanyer was writing about an actual estate, for readers who had seen it, and any formal gardens it may have featured would have come with meaning already infused. ${ }^{47}$ The naturalistic park offered a richer opportunity for interpretive shaping. Situated further from the house, at the edge of the patriarchal social order, it could better embody the "large microcosmic or philosophic ideas" characteristic of estate poems, which commonly contrasted the "civility and good order" of the estate with "what is outside." 48

The microcosm Lanyer creates is an intimate refuge where women read and write for one another, a "Paradice" 49 insulated from the matrimonial and social obligations that disrupt the relationships between them. Like most pleasure gardens, it mingles fancy with reality, rendering the boundaries of everyday life more flexible than usual. The new relation it fantasizes between its inhabitants and the order of the outside world is more complex than complete withdrawal, reflecting the garden's liminal status. For instance, even as Lanyer posits a utopian social hierarchy in her garden, based on virtue rather than rank, at the same time she repairs the Countess' relation to the standard hierarchy by replacing her philandering husband with an "Oake that did in height his fellowes passe, / As much as lofty trees, low growing grasse" (11. 55-6):

Where beeing seated, you might plainely see, Hills, vales, and woods, as if on bended knee They had appeard, your honour to salute,

Or to preferre some strange unlook'd for sute. (11. 67-70)

The only significant masculine presence in the garden, the oak embraces and protects the Countess $(11.61,64)$, providing her a country "seat" that yields quasi-feudal authority over imagined property. ${ }^{50}$ Lanyer compares the oak to a "Cedar "and a "Palme tree" $(11.57,61)$ to affirm the compatibility of this rank-determined "honour" with the Christian piety the Countess' actual husband so patently lacks. She also uses the garden to reimagine the service rela- 
tionship between herself and the Clifford women as friendship. Where status is based on virtue, not rank, friendship across conventional social categories becomes more plausible. Gardens were customarily sites of "plural, female community" 51 in larger households, and on Cookham's grounds friendship and patronage merge in perfect mutuality, epitomized by Margaret's "noble gratefulle minde, / Requiting each according to their kind" (11. 149-50). ${ }^{52}$ Lanyer often employs garden imagery to set out ideals of hierarchic relationships between women. In her dedication to Anne, she pictures Margaret sowing "the seeds of virtue" in her daughter (11. 58-9). She goes on to counsel Anne to sustain her ancestors' "honourable deeds" towards others, presumably including herself, by seeking to "cherish faire plants, suppresse unwholsom weeds" (11. 73-4, 78). Good gardening models virtuous fulfillment of duties toward inferiors: first in terms of cultivation and nurturing, and then with a plea for attention to "true worth" (1. 80) over position. Her metaphors may derive from experience of real gardens where women of different ranks worked side by side. Lawson's The Countrie Housewifes Garden suggests this was the norm. He recommends that the mistress of the house spend time guiding the women who tend her plantings, no matter how lowly.

The skill and paines of Weeding the Garden with weeding knives or fingers, I refer to her selfe, and her maides, willing them to take the opportunity after a showre of raine: with all I advise the Mistresse, eyther to be present her selfe, or to teach her maides to know hearbes from weedes. ${ }^{53}$

Later in the century Mary Rich would go out among her weeders with higher aims, "catechizing" them and "stirring them up to look after their souls." 54 Even beyond the household, gardens mediated female community across degrees. Lady Hoby records sharing plants with her neighbours, in April 1601 giving "some hearbes unto a good wiffe of Erley for his garden." 55 Lanyer imagines more intimate sharing grounded in love and respect.

But Cookham's Edenic community is fated to disintegrate from the beginning of the valediction, its harmonies portrayed as joys of a passing season. Fissures appear as early as line 95, when Anne's marriage disrupts the garden's fantasy of independence. Lanyer's wistful praise of Anne intimates that Cookham's moral fabric starts to unravel at the point when she submits to social convention:

And yet it grieves me that I cannot be

Neere unto her whose virtues did agree

With those faire ornaments of outward beauty

Which did enforce from all both love and dutie. 
Even in referring to the present, Lanyer locates Anne's 'virtues' oddly and emphatically in the past, as she does earlier when describing her as "that sweet Lady... /... / To honourable Dorset now espows'd, / In whose faire breast true virtue then was hous'd" (11. 99-102, 93, 95-6, emphasis mine). ${ }^{56}$ Lanyer is less overtly critical of Margaret though "occasions" beyond the garden walls claim her as well (1. 147). Together they leave Aemilia and Cookham behind, to rejoin the social order. ${ }^{57}$ The garden that doubles Lanyer and her verse now expresses the plight of a servant abandoned. Both are property subject to a household's shifting purposes-Lanyer doubly so, as dependent servant and as female writer unlikely to attract new male patronage. Equally fixed in their stations, they are powerless to follow the "great friends" who sporadically maintain them (1. 105).

Lanyer disrupts the fusion of poet and garden to protest these conditions. At the poem's center she launches into 33 lines of direct self-expression, rejecting Cookham's submissiveness and venting frustration and outrage. Where the liminal garden accedes to patriarchal convention, accommodating a dominant masculine presence, valuing 'honour' alongside virtue, and sorrowfully accepting the Cliffords' departure, Aemilia rails at the "Fortune" that divides people by rank and deplores the greater sort's lesser "love" (11. $104,109)$. When she appears to concede to conventional hierarchy, admitting her "Wit too weake to conster of the great" (1. 112), she does so only to collapse social strata with an analogy to all humanity's lowliness under Heaven. Her logic challenges Margaret to eschew the patronage system's injustices by taking God as her model, rewarding faithful service with "entire love" (1. 116).

When Lanyer redirects attention to the garden in line 121 her relation to it has changed. No longer does she allow it to stand in for her while she remains largely out of sight, present only as a poet function. Instead she begins to represent herself independently, as another woman in the garden interacting with Anne and Margaret. Alongside her continued projection of feeling into the landscape we now find her taking part in Anne's "sports" (1. 119) and sharing the Cliffords' perspective on the garden's fading pleasures, the "trees that were so glorious in our view" which shed "both flowres and fruit" (11. 133-4, emphasis mine). Eclipsing her earlier portrayal of the garden as a space of lived religion, she emphasizes human love and loss by focusing instead on its shattered community, and on the distinction between herself and the "speechelesse" garden she ventriloquizes (1. 138).

This distinction is especially striking in the second oak scene, where Lanyer leaves off remote observation to stand at Margaret's side as she bids the garden goodbye: 
110/ Renaissance and Reformation / Renaissance et Réforme

\begin{abstract}
To this faire tree, taking me by the hand, You did repeat the pleasures which had past, Seeming to grieve they could no longer last. And with a chaste, yet loving kisse tooke leave, Of which sweet kisse I did it soone bereave: Scorning a senceless creature should possesse So rare a favour, so great happinesse. (11. 162-8)
\end{abstract}

The trochee "taking," a rare mid-line inversion, disrupts the metrical flow to signal the episode's strain. ${ }^{58}$ Although it features the most intimate contact we witness between Aemilia and Margaret, the scene is marred by Margaret's equation of garden and poet, her failure to distinguish an emotionally charged landscape from a woman with real emotional and material needs. While she repeats "the pleasures which had past" to both, clearly valuing the memorial and communal functions of Aemilia's poem, instead of acknowledging the poet who gives the pleasures shape and meaning, she bestows her kiss directly on the garden, unconsciously neglecting the artist for the art. Aemilia defies the injustice by exposing the tree as the "sencelesse creature" it is without her poetic intervention (1. 166). In claiming the kiss for herself, she struggles to reconcile what is fair with her loving respect for Margaret, alternately characterizing herself as an "ingratefull Creature" doing a "great wrong" and as an unrepentant (if indirect) scorner of Margaret's priorities (11. 171, 174,167). ${ }^{59}$ The tonal difficulties of the scene, tending toward either bathos or wry humour, record her attempt at a light touch in a context of real ambivalence and risk. By taking the kiss that is rightfully hers, she fancifully rewrites the inequities she rages against at the center of the poem, seizing symbolic control of the "Fortune" that otherwise betrays her (11. 176, 104).

Yet in reality she is powerless to change the conditions of writing poetry in early modern England. After this brief fantasy, she reverts to the conflation of poet and garden, even reaccording sentience to the oak (11. 176-8). In Philomel's silence and Echo's death she registers the expiration of the female poetic voice as the poet is left behind and forgotten (11. 189-90, 199). At the same time, though, she also reassumes the perspective she shares with the Cliffords, recalling Echo's wonted replies to "our last words" (1. 200). The tension between the two viewpoints builds until poet and garden are decisively split in a grim nod to poetic immortality. While the garden/poem will potentially live forever, the poet will die (11. 205-6). Though bleak, this contrast frees Lanyer to end on a hopeful note, asserting a personal bond with Margaret that transcends the troubled circumstances of poetic production. She appeals to her as a friend, mortal and "unworthy" but bound at the heart 
by her virtues" "rich chaines" (11. 208, 210), which in a more perfect world would bind both ways.

The idealized patronage relationship Lanyer gestures toward is always already lost in the poem, not only in the past-ness of the garden's pleasures, but also in their original, inescapable contamination by the conditions of hierarchy, service, and poetic production that structure male-dominated society outside the garden's walls. Even before the poem begins, Lanyer has abandoned Cookham's flawed paradigm in favor of the higher ideal of Salve Deus Rex Judaeorum. She urges the Countess to accept the substitution, to exchange the beautiful "face" of the earthly paradise for a view of "Heavens bright face," Fortune for God's "Providence," and "worldly pleasures" for "Eternitie" (11. 22, 40, 26, 35-6). Though similarly betrayed by a patriarchal order, the resurrected Christ offers stronger shelter from the "waves of woe" that break in on the garden's fragile peace (1.34). With this new perspective comes a corresponding shift in how Lanyer figures her authorship. She and her poetry now double God's "most holy Writ" instead of a garden (1. 306). And in place of the Countess' fickle "grace," God's own "powerfull Grace" sustains her as a writer (11. 291-2). Lanyer's dream of transcending the patronage system is belied by the dedications proliferating at the head of the poem, as well as by her parting stanza complimenting the Countess as "the Articke Starre that guides [her] hand" (1. 1839). Yet in replacing the image of the woman in the garden with that of "the inestimable treasure of all elected soules, $"{ }^{\prime \prime 0}$ she asks us to consider her social constraints from a higher standpoint, by perceiving at the same time an alternate order where poet and patron share one status as souls serving God, and where any defects a poet may have "in Sexe, or Sence" or humble rank are compensated by His freely given love, never "call'd... away" by other "occasions." 61

\section{The College of the Holy Cross}

\section{Notes}

1. Isabella Whitney, A Sweet Nosgay, or Pleasant Posy, rpt. The Floures of Philosophie (1572) by Hugh Plat and A Sweet Nosgay (1573) and The Copy of a Letter (1567) by Isabella Whitney, ed. Richard J. Panofsky (Delmar, NY: Scholars' Facsimiles \& Reprints, 1982), p. A4v. In all quotations from texts in original spelling I have silently modernized $\mathrm{u} / \mathrm{v}$ and $\mathrm{i} / \mathrm{j}$ and expanded contractions.

2. Rachel Speght, Mortalities Memorandum, 1621, in The Polemics and Poems of Rachel Speght, ed. Barbara Lewalski (New York: Oxford University Press, 1996), line 100.

3. Mary Wroth, The Second Part of The Countess of Montgomery's Urania, ed. Josephine A. Roberts, completed by Suzanne Gossett and Janel Mueller (Tempe: Renaissance English Text Society and Arizona Center for Medieval and Renaissance Studies, 1999), p. 279. 
112/ Renaissance and Reformation / Renaissance et Réforme

Pamphilia's "wood" is a particular type of seventeenth-century garden composed of ornamental grounds more or less naturalistically planted with trees and traversed by paths.

4. Thomas Tusser, Five hundred pointes of good Husbandrie, 1573 (London: Henrie Denham, 1580), p. 42r.

5. Barnabe Googe, Foure bookes of husbandry, collected by M. Conradus Heresbachius, Counseller to the hygh and mighty Prince, the Duke of Cleve: Conteyning the whole arte and trade of husbandry, with the antiquitie, and commendation thereof. Newely Englished, and increased, by Barnabe Googe, Esquire (London: Richard Watkins, 1577), p. $48 \mathrm{v}$.

6. John B. Jackson, "The Past and Present of the Vernacular Garden," in The Vernacular Garden, ed. John Dixon Hunt and Joachim Wolschke-Bulmahn (Washington, D.C.: Dumbarton Oaks, 1993), p. 12. Citing Carl O. Sauer's Seeds, Spades, Hearths and Herds (Cambridge, MA: MIT Press, 1952), Jackson also notes that

anthropologists and agricultural historians have several explanations for the role of women in the traditional (and prehistoric) garden. The theory that the vernacular garden first evolved during a remote prehistoric time when matriarchal rule prevailed concurrently with the worship of the Earth Goddess or Earth Mother has received much attention in feminist literature and among deep ecologists. Another explanation is that our remote ancestral Indo-European agriculture was based (largely for climatic reasons) on the propagation of plants by means of seeds, whereas in tropical regions propagation was by means of roots or cuttings. Seeds can be, and often are, planted early in the winter and the seedlings are taken care of and provided with an artificial climate in the house, then transplanted in the spring. This protective role was taken over by the woman of the house, who assumed the same responsibility for young animals on the farm, thereby domesticating them. (p. 12)

7. Didymus Mountaine [Thomas Hill], The Gardener's Labyrinth, 1577, this edition 1652 , ed. Richard Mabey (Oxford: Oxford University Press, 1987), p. 23.

8. Achva Benzinberg Stein observes that "as with the Biblical past, gardens in the West have never been the exclusive province of either men or women. Rather, both have had a long association with the work of raising and nurturing plants and trees. In fact, it is one of the few occupations which seems to have been equally open to both" ("Thoughts on the Meaning of Gardens Occasioned by the Old Testament," Meanings of the Garden: Proceedings of a Working Conference to Explore the Social, Psychological and Cultural Dimensions of Gardens, May 14-17, 1987, University of California, Davis, ed. Mark Francis and Randolph T. Hester, Jr. [Davis: Center for Design Research, University of California, Davis, 1987], p. 352).

9. The handbooks often addressed an unspecified gender but betrayed gendered biases. Following Florentinus and Columella, for instance, Hill warns his otherwise unidentified readers to protect parts of their gardens from women, taking care

that no woman come or very seldome approach nigh to the fruits of the Gourdes or Cucumbers, for by her onely handling of them, they feeble and wither, which matter if it shall happen in the time of the Termes, doth either then slay the young tender fruits with her looke, or causeth them to be unsaverie, and spotted or corrupted within. (p. 190) 
Gervase Markham likewise fails to assign the garden to a distinctly feminine sphere in The Second Booke of the English Husbandman (London: T[homas] S[nodham], 1614), where he describes the "Pot-hearbs and Sallet-hearbs, which are the ornaments of the Husbandmans Kitchin or Table," and the "flowers, which either for their smels, beauties, or both, are the graces of his Chamber." Facsimile in The English Landscape Garden, ed. John Dixon Hunt [New York: Garland, 1982], p. 31). This qualifies Rebecca Bushnell's observation that "if there was a difference [in sixteenth and early seventeenth-century prescriptions for masculine and feminine experience in the garden], it lay in the attention to the decorative uses of flowers" (Green Desire: Imagining Early Modern English Gardens [Ithaca: Cornell University Press, 2003], p. 117).

10. Susan Dwyer Amussen, An Ordered Society: Gender and Class in Early Modern England (Oxford: Blackwell, 1988), p. 68.

11. Alicia Amherst observes that "the modern word garden is another form of this word... garth or yard, all are derived from an Aryan root meaning an enclosure" (A History of Gardening in England, 1896, 2nd ed. [Detroit: Singing Tree, 1969]), p. 6.

12. Amussen, pp. 68-9.

13. Laurie J. Shannon, "Emilia's Argument: Friendship and 'Human Title' The Two Noble Kinsmen," English Literary History 64 (1997), p. 661.

14. William Lawson, The Countrie Housewifes Garden, 1617, bound with A New Orchard and Garden, 1618, The English Landscape Garden, ed. John Dixon Hunt, pp. 10-1.

15. Googe, p. 64v.

16. William Lawson, The Countrie Housewifes, pp. 2-3.

17. For ornamented orchards, see for example William Lawson, A New Orchard and Garden, 1618, The English Landscape Garden, ed. John Dixon Hunt, especially pp. 57-8. Wildernesses at the late sixteenth-century estates of Nonsuch and Kenilworth housed many of the features listed here. For Nonsuch, see my essay "The Trials of Art: Testing Temperance in the Bower of Bliss and Diana's Grove at Nonsuch, Spenser Studies 20 (2005); and for Kenilworth, Robert Langham, A Letter, 1575, ed. R.J.P. Kuin, Medieval and Renaissance Texts 2 (Leiden: Brill, 1983), p. 37.

18. Rebecca W. Bushnell, A Culture of Teaching: Early Modern Humanism in Theory and Practice (Ithaca: Cornell University Press, 1996), p. 87. Consider Markham, for example, who boasts that he is "neither beholden to Pliny, Virgil, Columella, Varo, Rutillius, Libault, nor any other Forrainer, but onely to our owne best experienst Countreymen, whose daily knowledge hath made them most perfect in their professions" (Second Booke of the English Husbandman [London: T[homas] S[ondham], 1614], p. 13).

19. Hugh Platt, Floraes Paradise (London: H. L[ownes], 1608), pp. A3, 60.

20. Margaret Hoby, The Private Life of an Elizabethan Lady: The Diary of Lady Margaret Hoby 1599-1605, ed. Joanna Moody (Stroud: Sutton, 1998), 2 May 1600, 5 Oct 1603.

21. Francis Bacon, "Of Gardens," 1625, in Francis Bacon, ed. Brian Vickers (Oxford: Oxford University Press, 1996), p. 430.

22. Bushnell, Culture, p. 88.

23. Philip Sidney, A Defence of Poetry, 1579-80, ed. Jan Van Dorsten (Oxford: Oxford University Press, 1966), p. 20. 
114/ Renaissance and Reformation / Renaissance et Réforme

24. George Puttenham, The Arte of English Poesie, 1589, ed. Gladys Doidge Willcock and Alice Walker (Cambridge: Cambridge University Press, 1936), p. 307.

25. Sidney, p. 24.

26. I borrow from John Dixon Hunt's description of Renaissance Italian gardens, "much admired... for their fullness and variety; they offered miniature worlds, in the same way that an Elizabethan theatre like the Globe had done" (Garden and Grove: The Italian Renaissance Garden in the English Imagination, 1600-1750 [Princeton: Princeton University Press, 1986], p. 65).

27. Gervase Markham, The English Husbandman, 1613, The English Landscape Garden, ed. John Dixon Hunt, p. 120.

28. J.H. Wiffen, Historical Memoirs of the House of Russell (London: Longman, Rees, 1833), p. 118.

29. The Private Correspondence of Jane Lady Cornwallis; 1613-1644 (London: Bentley, 1842), 4 Oct 1618, 22 Oct 1617. Sir William Temple provides a lush, detailed description of Moor Park's garden in "Upon the Gardens of Epicurus" (1685). Although he specifically attributes the garden to Lucy, Countess of Bedford, the contract for the sale of the estate to Robert Cary, Earl of Monmouth, in 1631 records that the existing garden was laid out by William, $3^{\text {rd }}$ Earl of Pembroke, owner of the property from 1627 to 1630 . Garden historians have been unable to resolve this contradiction. See for example Roy Strong, The Renaissance Garden in England (London: Thames and Hudson, 1979), pp. 141, 144; and Christopher Thacker, The Genius of Gardening: The History of Gardens in Britain and Ireland (London: Weidenfeld, 1994), p. 109.

30. This ambiguous position also gave gardens a reputation for illicit indulgence of appetites. Phillip Stubbes complains of women abusing suburban gardens for trysting.

Then to these Gardens thei repaire when thei list, with a basket and a boy, where thei, meeting their sweete hartes, receive their wished desires. These Gardens are exelent places, and for the purpose; for if thei can speak with their dearlynges no where els, yet there thei maie be sure to meete them, and to receive the guerdon of their paines: thei know best what I meane.

He goes on: "And truely I thinke some of these places are little better then the Stewes and Brothell houses were in tymes past" (Phillip Stubbes's Anatomy of the Abuses in England in Shakespere's Youth, A.D. 1583, ed. Frederick J. Furnivall [London: Trübner, 1877-9], vol. 1, pp. 88, 89). Venetian ambassador Horatio Busino associates English gardens with appetites of another sort:

The numerous sorts of cherries and egriots [sour cherries] which one sees in Italy may well be desired in this kingdom, though certainly not enjoyed, for generally in the markets they only sell one single sort of very bad morella [bitter cherry]. Yet the English are extremely greedy of them, especially the women, buying them at the beginning of the season in bunches at the cost of an eye. Then these gentlewomen go with their squires to the fruit and flower gardens and orchards, to strive who can eat the most. It occurs to me here that a few months ago a leading lady ate 20 pounds of this fruit in competition with a cavalier who was scarcely seventeen. It is true that she ran the risk of her life, the exploit having confined her to her bed for many days. (The Diary of Horatio Busino, Chaplain of Pietro Contarini, Venetian Ambassador in England, in The Journals of Two Travellers in Elizabethan and Early Stuart Eng- 
land: Thomas Platter and Horatio Busino, ed. Peter Razzell [London: Caliban, 1995], 21 Sept 1618.)

Stubbes and Busino implicate both genders in these excesses, but significantly, in each case women are identified as initiating the retreat to the garden's privacy.

31. See especially Mark Girouard, Life in the English Country House: A Social and Architectural History (New Haven: Yale University Press, 1978).

32. On the issue of women's privacy in the domestic sphere, see Georgianna Ziegler, "My lady's chamber: female space, female chastity in Shakespeare," Textual Practice 4.1 (1990), pp. 73-90; Retha Warnicke, "Private and Public: The Boundaries of Women's Lives in Early Stuart England," Privileging Gender in Early Modern England, ed. Jean R. Brink (Kirksville: Sixteenth Century Journal Publishers, 1993), pp. 123-40; David Cressy, "Response: Private Lives, Public Performance, and Rites of Passage," Attending to Women in Early Modern England, ed. Betty S. Travitsky and Adele F. Seeff (Newark: University of Delaware Press, 1994), pp. 187-97; Sasha Roberts, "Shakespeare 'creepes into the womens closets about bedtime': women reading in a room of their own," Renaissance Configurations: Voices/Bodies/Spaces, 1580-1690, ed. Gordon McMullan (New York: St. Martin's Press, 1998), pp. 30-63; and Corinne S. Abate, ed., Privacy, Domesticity, and Women in Early Modern England (Aldershot: Ashgate, 2003).

33. Sir Henry Slingsby, The Diary of Sir Henry Slingsby, of Scriven, Bart., ed. D. Parson (London: Longham, 1836), p. 288, qtd. in David R. Coffin, The English Garden: Meditation and Memorial (Princeton: Princeton University Press, 1994), p. 60.

34. Anne Clifford, The Diaries of Lady Anne Clifford, ed. D.J.H. Clifford (Stroud: Sutton, 1990), pp. 32, 51-2, 57.

35. See Susanne Woods, "Women at the Margins in Spenser and Lanyer," Worldmaking Spenser: Explorations in the Early Modern Age, ed. Patrick Cheney and Lauren Silberman (Lexington: University Press of Kentucky, 2000). Interestingly, Woods argues here that "it is more than likely that Lanyer had read Spenser":

The 1590 Faerie Queene appeared while she was still Aemilia Bassano, at Elizabeth's court as the mistress of Henry Cary, Lord Hunsdon, who, as Lord Chamberlain, was responsible for court entertainments. If we credit her report to Simon Forman that "she hath bin favored moch of her mati [majesty, Queen Elizabeth]," Aemilia may even have been among those who heard Spenser read his poem "at timeley hours" in the Elizabethan court (Woods, ed. xviii; Spenser, Colin Clouts, 1. 362). One of Spenser's patrons was Margaret, Countess of Cumberland, who was to be Lanyer's principal patron and dedicatee of the Salve Deus. (pp. 107-8.)

36. John Smyth, Lives of the Berkeleys, 1618, ed. Sir J. Maclean (Gloucester, 1883), vol. 2, p. 362, qtd. in Girouard, p. 106.

37. J. Batchiler, The Virgins Pattern in the Exemplary Life and Lamented Death of Mrs. Susanna Perwich, Daughter of Mr. Robert Perwich, Who Departed This Life, Every Way a Rarely Accomplished Virgin in the Flower of Her Age, at Her Father's House in Hackney, Near London, in the County of Middlesex, July 3, 1661 (London: Simon Dover, 1661), pp. 13-4, qtd. in David R. Coffin, The English Garden: Meditation and Memorial (Princeton: Princeton University Press, 1994), p. 61.

38. Aemilia Lanyer, "To the Ladie Lucie, Countesse of Bedford," 1611, in The Poems of Aemilia Lanyer: Salve Deus Rex Judaeorum, ed. Susanne Woods (New York: Oxford 
116/ Renaissance and Reformation / Renaissance et Réforme

University Press, 1993), 11. 24-6. All subsequent quotations of Lanyer's poetry are from this edition.

39. Lanyer, "The Description of Cooke-ham," especially 11. 21ff and 11. 29ff. For the locus amoenus tradition, see Paul Tynegate Piehler, "Allegories of Paradise: Rhetoric and Archetype," Toward a Definition of Topos: Approaches to Analogical Reasoning, ed. Lynette Hunter (Basingstoke: Macmillan, 1991), p. 8.

40. Lanyer, Salve Deus Rex Judaeorum, 11. 185, $196 \mathrm{ff}$.

41. Lanyer, "To all vertuous Ladies in generall," 11. 32-3.

42. Lanyer, "The Authors Dreame to the Ladie Marie, the Countesse Dowager of Pembrooke," 11. 159-60, 87ff, 162.

43. In realigning the garden with the gazing poet/speaker, Lanyer follows such poems as Henry Constable's “Of his Mistress, upon Occasion of her Walking in a Garden” (1594), but adds poetic self-consciousness.

44. Lanyer, "To all vertuous Ladies in generall," 1. 33; "To the Ladie Susan, Countesse Dowager of Kent, and Daughter to the Duchesse of Suffolke," 1. 16.

45. Pamela Joseph Benson, "To Play the Man: Aemilia Lanyer and the Acquisition of Patronage," Opening the Borders: Inclusivity in Early Modern Studies, Essays in Honor of James V Mirollo, ed. Peter C. Herman (Newark: University of Delaware Press, 1999), pp. 245, 259. Susanne Woods agrees that Lanyer may have been Anne's music teacher (Lanyer: A Renaissance Woman Poet [New York: Oxford University Press, 1999], p. 37).

46. Woods, Woman Poet, p. 119.

47. What such meanings may have been depends on whose estate Lanyer is referring to in the poem. Countering editors' usual claim that Cookham was a royal manor leased by Lord William Russell, Margaret Clifford's brother, Richard Prior contends that there was no "royal house or royal palace anywhere near Cookham Dean or Cookham village" ("Aemilia Lanyer and Queen Elizabeth at Cookham,” Cahiers Élisabéthains 63 [2003] p.19). According to Prior, "There was a royal manor of Cookham, but, like any other manor in this context, it was not a house. It was a piece of territory within which the Crown had certain rights and duties. By 1592 it did not include the whole parish of Cookham, which then contained at least six other manors" (p. 31, n. 2). Prior argues instead that Lanyer refers to two country houses owned by the Hoby family: first, in lines 1-16, Bisham Abbey, residence of Lady Elizabeth Russell, her son Sir Edward Hoby, and his wife Lady Margaret, located "just over a mile, as the crow flies, from Cookham Dean," and then, in the rest of the poem, "most likely Dyars, located in Cookham Dean" (pp. 22, 27-8). Much of Prior's argument rests on his efforts to understand the "princely Palace" of line 5 as "princely Pallas," or Queen Elizabeth. Given the wonderfully active garden in Lanyer's poem, I do not share Prior's view that reading the "Palace" as a house yields the line "a rather strained sense, since it portrays an inanimate object 'willing' Lanyer to write” (p. 19). Nevertheless, his extensive research into the poem's context offers important new perspectives on Lanyer's work.

48. The first formulation is Alastair Fowler's, from The Country House Poem: A Cabinet of Seventeenth-Century Estate Poems and Related Items (Edinburgh: Edinburgh University Press, 1994), p. 4. Barbara Lewalski lists the second among the "common topics [that] characterize poems in the genre during the period 1600 to 1660 " in "The Lady of the 
Country-House Poem," The Fashioning and Functioning of the British Country House, ed. Gervase Jackson-Stops et al., Studies in the History of Art 25, Center for Advanced Study in the Visual Arts, Symposium Papers X (Washington, D.C.: National Gallery of Art, 1989), p. 262.

49. Lanyer, Salve Deus Rex Judaeorum, 1. 21.

50. Barbara Lewalski also remarks on the oak's distinction as "almost the only element of nature gendered male" on the estate (Writing Women in Jacobean England [Cambridge, MA: Harvard University Press, 1993], p. 238).

51. Shannon, p. 676.

52. Alastair Fowler's reminder that estate poems are "always related to ceremonies of hospitality and hierarchic obligation" highlights the patronage relationships that underlie this community for Lanyer (p. 14). For a shrewd analysis of Lanyer's relation to patronage, see Su Fang Ng, "Aemilia Lanyer and the Politics of Praise," English Literary History 67 (2000), pp. 433-51.

53. Lawson, Countrie Housewifes, p. 19.

54. Mary Rich, Lady Warwick, Memoir of Lady Warwick Also Her Diary (London, n.d.), entry for September 6, 1671, qtd. in David R. Coffin, The English Garden: Meditation and Memorial (Princeton: Princeton University Press, 1994), p. 64. With reference to household records, Alicia Amherst confirms that the weeding of great gardens "was usually done by women" (Amherst, p. 105).

55. Hoby, 27 April 1601. Moody's note identifies "Erley" as "Everley, a small hamlet very near Hakness," and acknowledges the substitution of "his" for "her."

56. Compare her dedication to Anne, where nine stanzas detailing the proper relation of rankdetermined honour to virtue (11. 17-88) are belatedly and inadequately offset by three affirming Anne's perfection (11. 89-112). In tracing Lanyer's muted critique of Anne I hope to qualify Barbara Lewalski's idealistic reading of the women as a "guiltless trio" ("Lady of the Country-House Poem," p. 272). Kari Boyd McBride offers a more extreme reading of the "tension between Lanyer and the women of Cooke-ham and between Lanyer and her potential patrons" in "Remembering Orpheus in the Poems of Aemilia Lanyer" (Studies in English Literature 38.1 [1998] p. 87-108). McBride perceptively argues that Lanyer takes advantage of the loss of female community to "construct her vocation" (p. 99).

57. Janel Mueller identifies Lanyer's Garden of Gethsemane as another space mediating between protected private and threatening public. She observes that "the garden's atmospheric darkness is liminal - a space no longer of private familiarity and intimacy, like the meal [Christ] has just shared with his twelve disciples, but not quite yet a public space of arrest, interrogation, and judicial sentencing" ("The Feminist Poetics of 'Salve Deus Rex Judaeorum," in Aemilia Lanyer: Gender, Genre, and the Canon, ed. Marshall Grossman [Lexington: University Press of Kentucky, 1998], p. 109.) Cookham also first appears at "night" (Salve Deus Rex Judaeorum, 1. 19).

58. To make sense of the full passage, I infer a period at the end of line 161, so that "To this faire tree" modifies only "You did repeat the pleasures which had past," and not the preceding "Where many a learned Booke was read and skand." 
118/ Renaissance and Reformation / Renaissance et Réforme

59. My reading of the episode runs counter to Naomi J. Miller's, who claims that "through her verbal recounting... of the mute kiss of the 'Mistris,' at once deflected and redirected through the body of the tree, the female poet finally constructs a position for herself as author outside the realm of potential threat or competition" ("[M]other Tongues: Maternity and Subjectivity," in Aemilia Lanyer: Gender, Genre, and the Canon, ed. Marshall Grossman [Lexington: University Press of Kentucky, 1998]). Based on Aemilia's conflicted response to the kiss, I would object that this is the moment when the "threat" is sharpest for the female poet, who suddenly finds herself competing with her own creation for her patron's favor. Similarly, where Barbara Lewalski sees the oak offering "no temptation... only contentment," I would argue that at a purely human level the oak offers a temptation analogous to that of Eden's fatal tree-to privilege creation over creator (Lewalski, Writing Women, p. 238).

60. Lanyer, "To the Ladie Margaret Countesse Dowager of Cumberland," 1. 29.

61. Lanyer, Salve Deus Rex Judaeorum, 1. 290; “The Description of Cooke-ham," 1. 147. 